\title{
Am/Cm Target Glass Durability Dependence on pH (U)
}

by

\author{
W. E. Daniel
}

Westinghouse Savannah River Company

Savannah River Site

Aiken, South Carolina 29808

D. R. Best

\section{DISCLAIMER}

This report was prepared as an account of work sponsored by an agency of the United States Government. Neither the United States Government nor any agency thereof, nor any of their employees, makes any warranty, express or implied, or assumes any legal liability or responsibility for the accuracy, completeness, or usefulness of any information, apparatus, product, or process disclosed, or represents that its use would not infringe privately owned rights. Reference herein to any specific commercial product, process, or service by trade name, trademark, manufacturer, or otherwise does not necessarily constitute or imply its endorsement, recommendation, or favoring by the United States Government or any agency thereof. The views and opinions of authors expressed herein do not necessarily state or reflect those of the United States Government or any agency thereof.

\section{DISTRIEUTION OF THIS DOCUMENT IS UNLIMTTED}

DOE Contract No. DE-AC09-89SR18035

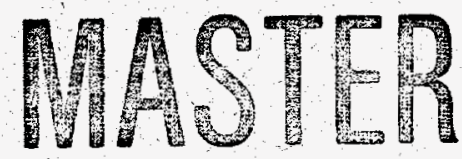

This paper was prepared in connection with work done under the above contract number with the $U$. $S$.

Department of Energy. By acceptance of this paper, the publisher and/or recipient acknowledges the U.S. Government's right to retain a nonexclusive, royatty-free license in and to any copyright covering this paper, along with the right to reproduce and to authorize others to reproduce all or part of the copyrighted paper. 


\section{DISCLAIMER}

Portions of this document may be illegible in electronic image products. Images are produced from the best available original document. 


\section{DISCLAIMER}

This report was prepared as an account of work sponsored by an agency of the United States Government. Neither the United States Government nor any agency thereof, nor any of their employees, makes any warranty, express or implied, or assumes any legal liability or responsibility for the accuracy, completeness, or usefulness of any information, apparatus, product, or process disclosed, or represents that its use would not infringe privately owned rights. Reference herein to any specific commercial product, process, or service by trade name; trademark, manufacturer, or otherwise does not necessarily constitute or imply its endorsement, recommendation, or favoring by the United States Government or any agency thereof. The views and opinions of authors expressed herein do not necessarily state or reflect those of the United States Government or any agency thereof.

This report has been reproduced directly from the best available copy.

Available to DOE and DOE contractors from the Office of Scientific and Technical Information, P.O. Box 62, Oak Ridge, TN 37831; prices available from (615) 576-8401.

Available to the public from the National Technical Information Service, U.S. Department of Commerce; 5285 Port Royal Road, Springfield, VA 22161. 
Westinghouse Savannah River Company Savannah River Technology Section
WSRC-MS-96-0165

Revision 0

CC: E. W. Holtzscheiter, 773-A

C. T. Randall, 704-T

L. F. Landon, 704-T

M. J. Plodinec, 773-A

K. G. Brown, 704-1T

A. H. Gray, 773-A

D. H. Miller, 704-1T

N. H. Kuehn, 704-T

A. S. Choi, 704-1T

S. B. Beck, 704-T

N. E. Bibler, 773-A

C. M. Jantzen, 773-A

D. F. Bickford, 773-A

J. M. Pareizs, 773-A

Keywords: Actinide Glass, $\mathrm{Am} / \mathrm{Cm}$ Glass, $\mathrm{pH}$ dependence, durability

March 4, 1996

\section{Am/Cm Target Glass Durability Dependence on pH (U)}

At the Westinghouse Savannah River Company near Aiken, South Carolina, a process is being developed to safely vitrify all of the highly radioactive americium $/$ curium $(\mathrm{Am} / \mathrm{Cm})$ material and a portion of the other fissile actinide materials stored on site. One goal of this campaign is to provide Oak Ridge National Laboratory with the excess $\mathrm{Am} / \mathrm{Cm}$ so it can be recycled as opposed to simply disposing of it as waste. The vitrification will allow safe transportation of the $\mathrm{Am} / \mathrm{Cm}$ to Oak Ridge as well as safe storage once it arrives. The $\mathrm{Am} / \mathrm{Cm}$ Target glass being used in this project has been specifically designed to be extremely durable in aqueous environments while it can be selectively attacked by nitric acid to recover the valuable Am and $\mathrm{Cm}$ isotopes. Similar glass compositions could be used for storage and retrieval of other actinides on the WSRC site. Previous reports have presented the time, temperature, and compositional dependence of the $\mathrm{Am} / \mathrm{Cm}$ glass durability. This paper will show results from a pH study on the $\mathrm{Am} / \mathrm{Cm}$ Target glass durability. The data indicate that the $\mathrm{Am} / \mathrm{Cm}$ Target Glass durability decreases as $\mathrm{pH}$ decreases from a neutral reading. These findings support the extraction of the valuable isotopes from the glass using nitric acid. 


\section{Introduction}

Several experiments had been performed on the $\mathrm{Am} / \mathrm{Cm}$ Target glass to examine its durability in terms of time and temperature. This report discusses some experiments to examine the $\mathrm{pH}$ dependence of the $\mathrm{Am} / \mathrm{Cm}$ Target durability. All the experiments were performed using the Product Consistency Test developed at WSRC and discussed in the next section.

\section{Product Consistency Test Description}

Product Consistency Tests (PCT Test Method B) were performed on Am/Cm Target and Approved Reference Material (ARM) glasses at WSRC Savannah River Technology Center (SRTC). The PCT's were done according to the requirements in the American Society for Testing and Materials (ASTM) Test Method C1285-94 Determining Chemical Durability of Nuclear Waste Glasses: The Product Consistency Test $(P C T)^{1}$.

Tests were performed on the Am/Cm Target glasses in triplicate for various $\mathrm{pH}$ buffered solutions. Duplicate blanks were run for each $\mathrm{pH}$ buffer. Table I lists the elemental leachate concentrations for the $\mathrm{Am} / \mathrm{Cm}$ Target glass where $\mathrm{pH}$ leachates were $\mathrm{pH} \mathrm{1,} \mathrm{pH} 4, \mathrm{pH} 7, \mathrm{pH} 10$, $\mathrm{pH} 13$ and a standard PCT run $\left(90 \pm 2^{\circ} \mathrm{C}\right.$, DI H20 as leachate) on the Approved Reference Material (ARM) where $\mathrm{pH}$ ranges between 6 and 8. In Table I, BLK is the abbreviation for blank and ACT is short for Am/Cm Target glass. Table II lists the oxide compositions of the $\mathrm{Am} / \mathrm{Cm}$ Target and ARM-1 glasses.

Each glass was ground using a Tekmar grinder with tungsten carbide blades. The ground glass was then sieved and a 100-200 mesh size collected in a beaker. The glasses were then washed by forcibly adding $15-20 \mathrm{ml}$ of de-ionized water to the beaker and then decanting. This process was done three times. The glasses were also washed twice by forcibly adding 15-20 ml of de-ionized water, placing the beaker in an ultrasonic water bath for two minutes and then decanting. The process was repeated with ethyl alcohol. The glasses were then placed in a convection oven over night to dry.

Teflon ${ }^{\circledR}$ and stainless steel vessels were then prepared to receive the dried samples. First, the vessels and lids were cleaned by soaking them in $0.16 \mathrm{M}$ Nitric $\mathrm{Acid}\left(\mathrm{HNO}_{3}\right)$ at $90^{\circ} \mathrm{C} \pm 10^{\circ} \mathrm{C}$ for approximately one hour on a hot plate. These items were then rinsed with de-ionized water. The vessels were then soaked in fresh de-ionized water at $90^{\circ} \mathrm{C} \pm 10^{\circ} \mathrm{C}$ for about an hour on a hot plate. The vessels were filled $80 \%$ full with de-ionized water ( $\mathrm{pH} 5.0-7.0)$, capped, and placed in a convection oven at $90^{\circ} \mathrm{C} \pm 2{ }^{\circ} \mathrm{C}$ for 16 hours. The $\mathrm{pH}$ values of the water after the 16 hour period were still between the $\mathrm{pH} 5.0$ - 7.0 range. For the $\mathrm{pH} 1$ and $\mathrm{pH} 4$ tests, approximately 3.5 grams of each glass were then added to the cleaned Teflon ${ }^{\circledR}$ vessels and their weights recorded. Stainless steel vessels were not used for these two tests due to $\mathrm{HCl}$ in the $\mathrm{pH} 1$ and $\mathrm{pH} 4$ buffers. For the $\mathrm{pH} 7, \mathrm{pH} 10$ and $\mathrm{pH} 13$ tests, approximately 1.5 grams of each glass were added to the cleaned stainless steel vessels and their weights recorded.

\footnotetext{
1 ASTM C 1285-94, Annual Book of ASTM Standards, American Society for Testing and Materials, Committee C26 on Nuclear Fuel Cycle, Subcommittee C26.13 on Repository Waste Package Materials Testing, Volume 12.01, 1994.
} 
Table I. PCT Leachate Concentrations for Am/Cm Target (ACT) and ARM Glasses

\begin{tabular}{|c|c|c|c|c|c|c|c|c|c|c|c|}
\hline (ppm) & $\mathbf{S i}$ & $\mathbf{P b}$ & B & Al & $\mathbf{N d}$ & $\mathbf{B a}$ & $\mathbf{N a}$ & $\mathbf{L i}$ & $\mathbf{E u}$ & La & $\mathrm{Ce}$ \\
\hline BLK-1-PH1 & 5.70 & $<0.20$ & 0.167 & $<0.15$ & $<0.30$ & $<0.01$ & 1200 & $<0.015$ & $<0.01$ & 0.057 & $<0.15$ \\
\hline BLK-2-PH1 & 5.51 & $<0.20$ & 0.131 & 0.17 & $<0.30$ & 0.017 & 1220 & $<0.015$ & $<0.01$ & 0.103 & $<0.15$ \\
\hline ACT-1-PH1 & 110 & 1520 & 197 & 46.4 & 1140 & 233 & 1218 & $<0.30$ & 77.0 & 2328 & 690 \\
\hline ACT-2-PH1 & 109 & 1530 & 197 & 47.3 & 1140 & 233 & 1208 & $<0.30$ & 76.6 & 2313 & 684 \\
\hline ACT-3-PH1 & 108 & 1500 & 193 & 46.8 & 1130 & 228 & 1193 & $<0.30$ & 77.2 & 2281 & 686 \\
\hline BLK-1-PH4 & $<0.05$ & $<0.20$ & 0.244 & $<0.15$ & $<0.30$ & 0.023 & 1.67 & $<0.015$ & $<0.01$ & 0.04 & $<0.15$ \\
\hline BLK-2-PH4 & $<0.05$ & $<0.20$ & 0.147 & $<0.15$ & $<0.30$ & 0.022 & 0.334 & $<0.015$ & $<0.01$ & $<0.03$ & $<0.15$ \\
\hline ACT-1-PH4 & 86.7 & 6.20 & 66.7 & 1.36 & 186 & 37.3 & 0.927 & 0.016 & 16.0 & 253 & 70.6 \\
\hline ACT-2-PH4 & 87.8 & 2.91 & 88.0 & 1.07 & 202 & 43.5 & 1.14 & 0.019 & 19.0 & 229 & 68.0 \\
\hline ACT-3-PH4 & 82.3 & 3.01 & 80.8 & 1.04 & 205 & 43.3 & 1.08 & 0.017 & 19.6 & 233 & 69.4 \\
\hline BLK-1-PH7 & 0.183 & $<0.20$ & 0.026 & $<0.15$ & $<0.30$ & $<0.01$ & 0.216 & $<0.015$ & 0.064 & 0.096 & $<0.15$ \\
\hline BLK-2-PH7 & 0.401 & $<0.20$ & 0.011 & $<0.15$ & $<0.30$ & $<0.01$ & 0.138 & $<0.015$ & 0.064 & 0.096 & $<0.15$ \\
\hline АCT-1-PH7 & 3.74 & $<0.20$ & 0.642 & 0.223 & $<0.30$ & 0.678 & 0.171 & $<0.015$ & $<0.01$ & $<0.03$ & $<0.15$ \\
\hline ACT-2-PH7 & 7.03 & $<0.20$ & 0.582 & 0.415 & $<0.30$ & 0.123 & 0.447 & 0.033 & $<0.01$ & $<0.03$ & $<0.15$ \\
\hline ACT-3-PH7 & 3.84 & $<0.20$ & 0.698 & 0.311 & $<0.30$ & 0.608 & 0.198 & 0.019 & $<0.01$ & $<0.03$ & $<0.15$ \\
\hline BLK-1-PH10 & 3.43 & $<0.20$ & 0.904 & 0.226 & $<0.30$ & $<0.01$ & 21.1 & $<0.015$ & 0.064 & 0.096 & $<0.15$ \\
\hline BLK-2-PH10 & 4.26 & $<0.20$ & 0.573 & 2.43 & $<0.30$ & $<0.01$ & 21.1 & $<0.015$ & 0.064 & 0.095 & $<0.15$ \\
\hline ACT-1-PH10 & 33.8 & $<0.20$ & 6.83 & 8.99 & $<0.30$ & 0.044 & 21.0 & 0.058 & $<0.01$ & $<0.03$ & $<0.15$ \\
\hline ACT-2-PH10 & 32.9 & $<0.20$ & 6.23 & 8.56 & $<0.30$ & 0.036 & 20.9 & 0.043 & $<0.01$ & $<0.03$ & $<0.15$ \\
\hline ACT-3-PH 10 & 36.1 & $<0.20$ & 6.18 & 7.38 & $<0.30$ & 0.036 & 27.1 & 0.078 & $<0.01$ & 0.036 & $<0.15$ \\
\hline BLK-1-PH13 & 0.701 & $<0.20$ & 0.366 & 1.56 & $<0.30$ & $<0.01$ & 18.9 & 0.482 & 0.064 & 0.096 & $<0.15$ \\
\hline BLK-2-PH13 & 0.804 & $<0.20$ & 0.325 & 0.853 & $<0.30$ & $<0.01$ & 18.1 & 0.51 & 0.064 & 0.094 & $<0.15$ \\
\hline ACT-1-PH13 & 129 & 50.3 & 25.3 & 44.5 & $<0.30$ & 0.505 & 17.5 & 0.575 & $<0.01$ & $<0.03$ & $<0.15$ \\
\hline ACT-2-PH13 & 128 & 51.5 & 25.8 & 44.7 & $<0.30$ & 0.492 & 17.4 & 0.572 & $<0.01$ & $<0.03$ & $<0.15$ \\
\hline ACT-3-PH13 & 132 & 50.7 & 27.0 & 44.9 & $<0.30$ & 0.531 & 18.2 & 0.594 & $<0.01$ & $<0.03$ & $<0.15$ \\
\hline ARM 1-PH7 & 66.5 & $<0.20$ & 17.4 & 5.19 & $<0.30$ & 0.020 & 40.2 & 15.6 & $<0.01$ & $<0.03$ & $<0.15$ \\
\hline ARM 2-PH7 & 65.6 & $<0.20$ & 17.4 & 5.18 & $<0.30$ & 0.019 & 40.2 & 15.5 & $<0.01$ & $<0.03$ & $<0.15$ \\
\hline
\end{tabular}


Table II. Am/Cm Target and ARM-1 Glass Compositions

\begin{tabular}{|c|c|c|}
\hline Oxide & $\begin{array}{c}\text { ARM-1 } \\
\text { Wt } \% \\
\end{array}$ & $\begin{array}{c}\mathrm{Am} / \mathrm{Cm} \text { Target } \\
\mathrm{Wt} \%\end{array}$ \\
\hline $\mathrm{Al}_{2} \mathrm{O}_{3}$ & 5.59 & 6.24 \\
\hline $\mathrm{B}_{2} \mathrm{O}_{3}$ & 11.3 & 6.19 \\
\hline $\mathrm{BaO}$ & $*$ & 2.25 \\
\hline $\mathrm{CaO}$ & 2.24 & $*$ \\
\hline $\mathrm{CeO}_{2}$ & 1.51 & $*$ \\
\hline $\mathrm{Ce}_{2} \mathrm{O}_{3}$ & $*$ & 8.22 \\
\hline $\mathrm{Cs}_{2} \mathrm{O}$ & 1.17 & $*$ \\
\hline $\mathrm{Eu}_{2} \mathrm{O}_{3}$ & $*$ & 0.72 \\
\hline $\mathrm{Fe}_{2} \mathrm{O}_{3}$ & $*$ & $*$ \\
\hline $\mathrm{FeO}$ & $*$ & $*$ \\
\hline $\mathrm{K}_{2} \mathrm{O}$ & $*$ & $*$ \\
\hline $\mathrm{La}_{2} \mathrm{O}_{3}$ & $*$ & 23.3 \\
\hline $\mathrm{Li}_{2} \mathrm{O}$ & 5.08 & $*$ \\
\hline $\mathrm{MgO}$ & $*$ & * \\
\hline $\mathrm{MnO}$ & * & * \\
\hline $\mathrm{MnO}_{2}$ & $*$ & * \\
\hline $\mathrm{MoO}_{3}$ & 1.66 & * \\
\hline $\mathrm{Na}_{2} \mathrm{O}$ & 9.66 & $*$ \\
\hline $\mathrm{Nd}_{2} \mathrm{O}_{3}$ & 5.96 & 11.62 \\
\hline $\mathrm{PbO}$ & $*$ & 13.48 \\
\hline $\mathrm{SiO}_{2}$ & 46.5 & 27.97 \\
\hline $\mathrm{TiO}_{2}$ & 3.21 & $*$ \\
\hline $\mathrm{ZnO}$ & 1.46 & $*$ \\
\hline $\mathrm{ZrO}_{2}$ & 1.8 & $*$ \\
\hline
\end{tabular}

*not applicable

An Orion $\mathrm{pH}$ meter was calibrated using 4, 7, and $10 \mathrm{pH}$ buffers. The $\mathrm{pH}$ buffers $1,4,7,10$ and 13 were prepared and an initial $\mathrm{pH}$ was recorded as shown in Table III .

Table III. Preparation of pH Buffer Solutions

\begin{tabular}{|c|c|c|}
\hline $\mathrm{pH}$ solution & Preparation & Initial $\mathrm{pH}$ \\
\hline $\mathrm{pH} \mathrm{1}$ & Potassium Chloride/Hydrochloric acid & 1.64 \\
\hline $\mathrm{pH} 4$ & $\begin{array}{c}\text { Potassium Hydrogen } \\
\text { Phthalate/Hydrochloric acid }\end{array}$ & 4.07 \\
\hline $\mathrm{pH} \mathrm{7}$ & $\begin{array}{c}\text { Potassium Orthophosphate di- } \\
\text { H/Potassium Orthophosphate mono-H }\end{array}$ & 7.17 \\
\hline $\mathrm{pH} \mathrm{10}$ & $\begin{array}{c}\text { Potassium Orthophosphate/Potassium } \\
\text { Orthophosphate mono-H }\end{array}$ & 9.91 \\
\hline $\mathrm{pH} \mathrm{13}$ & Calcium Chloride/Potassium Hydroxide & 12.48 \\
\hline
\end{tabular}

For the pH buffer tests 1 and 4, approximately 35 grams of the buffer was added to each vessel and a total weight of the vessel, water, and glass was recorded. For the $\mathrm{pH}$ buffer tests 7,10 , and 13 , approximately 15 grams of the buffer was added to each vessel and a total weight of the 
vessel, water, and glass was recorded. The vessels were capped and then placed in a Blue $\mathrm{M}$ convection oven at $90^{\circ} \pm 2^{\circ} \mathrm{C}$. The following day, the vessels were removed and checked to make sure that they were still tightly sealed. The oven temperature was monitored at half an hour intervals during the course of the study, using an Omega Thermocouple Thermometer.

After the seven day test period was complete, the vessels were taken out of the convection oven and allowed to cool. The vessels were weighed and the weight recorded. All of the samples had a weight loss of less than $1 \%$ over the course of the study. Each vessel was then uncapped and a $\mathrm{pH}$ taken. The final $\mathrm{pH}$ levels of the ARM glass standards were 10.22, 10.26, and 10.27. The final $\mathrm{pH}$ of the buffer $\mathrm{pH} 1$ tests were $2.85,2.89$, and 3.13, buffer $\mathrm{pH} 4$ tests were 5.02 , 5.21 , and 5.28, buffer $\mathrm{pH} 7$ test were $6.55,6.81$, and 7.86 , buffer $\mathrm{pH} 10$ tests were $10.35,10.40$, and 10.41 , and buffer 13 tests were $13.20,13.21$, and 13.24 .

Sterilized syringes and filters were used to filter the leachate into pre-sterilized vials. A total of $20 \mathrm{ml}$ was filtered into each vial and then $200 \mathrm{ml}$ of ultrapure nitric acid was added. The samples were then submitted for elemental analyses on an Inductively Coupled Plasma-Atomic Emission Spectrometer (ICP-AES). Elements analyzed in the blanks, ARM glass standard, and Löffler glass leachates included silicon $(\mathrm{Si})$, lead $(\mathrm{Pb})$, boron $(\mathrm{B})$, aluminum $(\mathrm{Al})$, neodymium $(\mathrm{Nd})$, barium $(\mathrm{Ba})$, europium $(\mathrm{Eu})$, lanthanum $(\mathrm{La})$, and cerium $(\mathrm{Ce})$. These leachate analyses are shown in Table I. In the next section, the durability of the glass is calculated from this data.

\section{Durability Calculation}

Data obtained from the PCT Tests were analyzed to determine the durability of Am/Cm Target glass as a function of $\mathrm{pH}$. In the past, the concentrations of silica and boron have been examined since these elements leach the easiest and are therefore good indicators of a glass's durability.

Since there is an interest in recovering the actinides in the $\mathrm{Am} / \mathrm{Cm}$ Target glass, the concentrations of the actinide surrogates neodymium $(\mathrm{Nd})$, lanthanum $(\mathrm{La})$, and cerium $(\mathrm{Ce})$ were also examined. First, the elemental release data was zeroed against the blanks to provide an unbiased representation of the leachate concentrations. Next, the normalized release of each element $i$ was calculated using the following equation:

$$
N R_{i}=\frac{p p m_{i}}{1000 \bullet w_{i}}
$$

where $\mathrm{NR}_{\mathrm{i}}$ is the normalized release of element $\mathrm{i}$ in grams of glass dissolved per liter of solution, $\mathrm{ppm}_{\mathrm{i}}$ is element $\mathrm{i}$ concentration in solution, and $w_{i}$ is the weight fraction of element $i$ in the glass. This calculation assumes the density of the solution is about that of water or $1 \mathrm{gram} / \mathrm{milliliter}$. For the Am/Cm Target and ARM glasses, the weight fraction of each of the elements examined are given in Table IV. It is common practice to look at the log-normal concentration of glass leachates which is simply the log of the NR values from equation 1 . Table $\mathrm{V}$ shows the raw ppm releases along with the normal (NR) and log-normal (LNR) releases for the $\mathrm{Am} / \mathrm{Cm}$ Target glass data that were analyzed for the series of $\mathrm{pH}$ experiments discussed earlier. 
Table IV. Weight Fraction of Elements in Am/Cm Target and ARM Glasses

\begin{tabular}{|c|c|c|c|c|c|}
\hline Glass & S i & B & Nd & La & Ce \\
\hline Am/Cm Target & 0.120 & 0.0164 & 0.0841 & 0.144 & 0.0605 \\
ARM & 0.224 & 0.0361 & 0.0526 & 0 & 0.0127 \\
\hline
\end{tabular}

The data in Table $\mathrm{V}$ is plotted in Figures 1 through 6. The lines in the figures are just for illustration of the general shape of the data. Looking at Figures 1 through 3, one can see that as the $\mathrm{pH}$ moves away from a neutral position, the durability decreases as evidenced by the normalized boron release going from about 0 grams of glass per liter at a $\mathrm{pH}$ of 7 to about 12 grams of glass per liter at a pH of 3. Figures 4 through 6 show a similar type of behavior for the actinide surrogates in the $\mathrm{Am} / \mathrm{Cm}$ Target glass. As the $\mathrm{pH}$ decreases from a neutral value, the release of the actinide surrogate jumps from about 0 grams of glass per liter to about 14 grams of glass per liter. These results support the plan to use nitric acid to extract the valuable actinide isotopes from the $\mathrm{Am} / \mathrm{Cm}$ Target glass. 


\begin{tabular}{|c|c|c|}
\hline 超 & 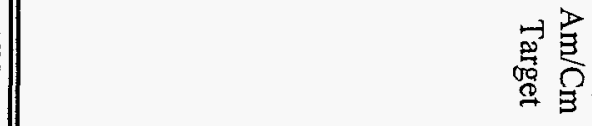 & 郒 \\
\hline $\mid \begin{array}{ll}0 & 0 \\
0 & 0 \\
\text { Ni } & 0\end{array}$ & 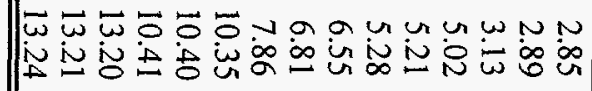 & 营 \\
\hline ir 2 & 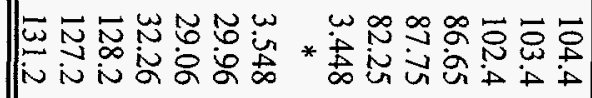 & 屏 \\
\hline 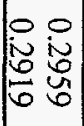 & 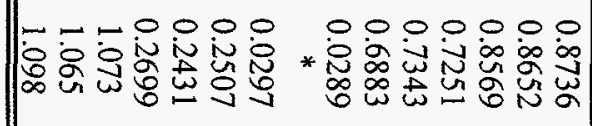 & 觉 \\
\hline 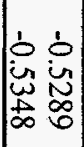 & 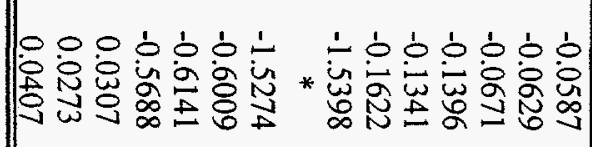 & 党 \\
\hline 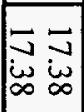 & 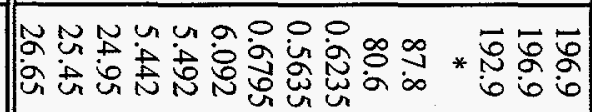 & $\infty$ \\
\hline 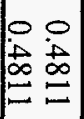 & 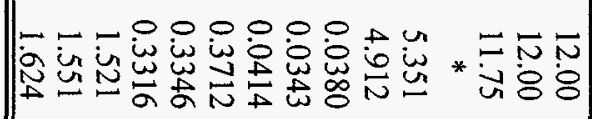 & 正营 \\
\hline 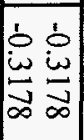 & 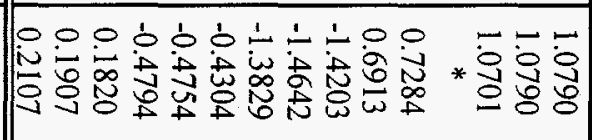 & 莺 \\
\hline 100 & ||lloll & ż \\
\hline 00 & 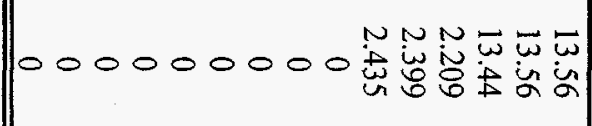 & 迨帘 \\
\hline * & 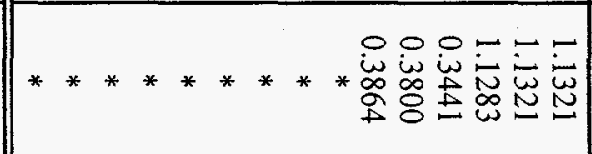 & 突 \\
\hline$* *$ & 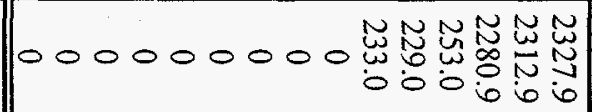 & 5 \\
\hline * & 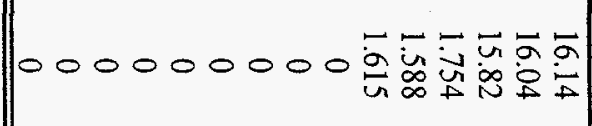 & 疍 \\
\hline$*$ & * * & 常 \\
\hline 00 & 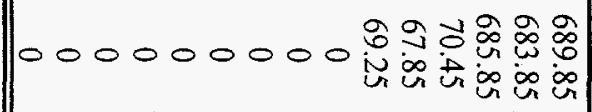 & 8 \\
\hline 00 & 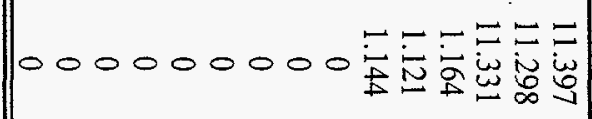 & 迹忞 \\
\hline & 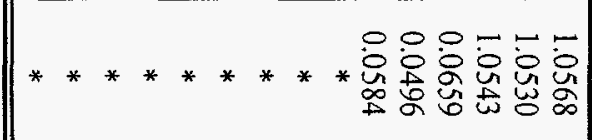 & 赇 \\
\hline
\end{tabular}




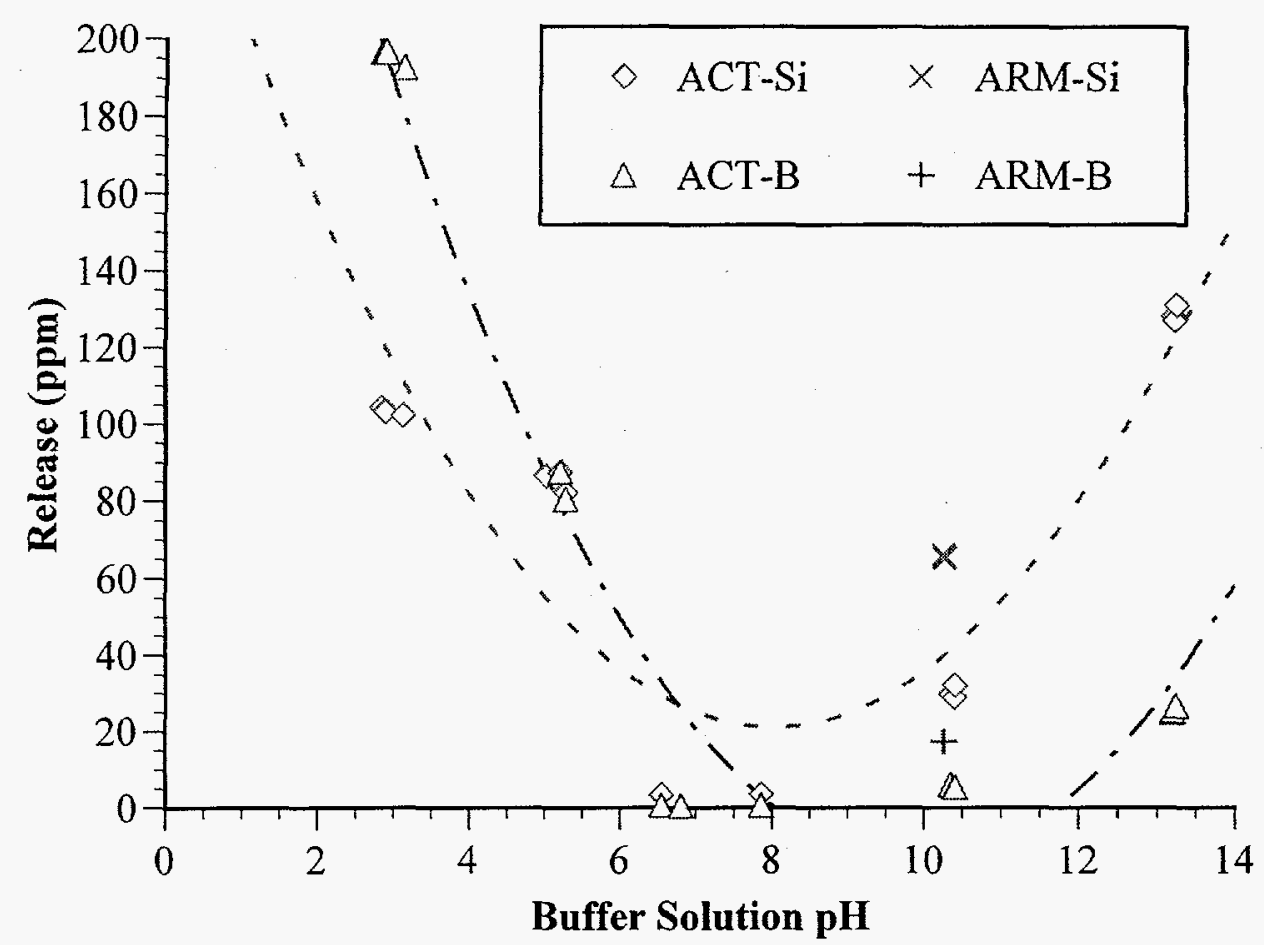

Figure 1. Am/Cm Target (ACT) silica and boron leachate concentrations for different $\mathrm{pH}$ buffered solutions.

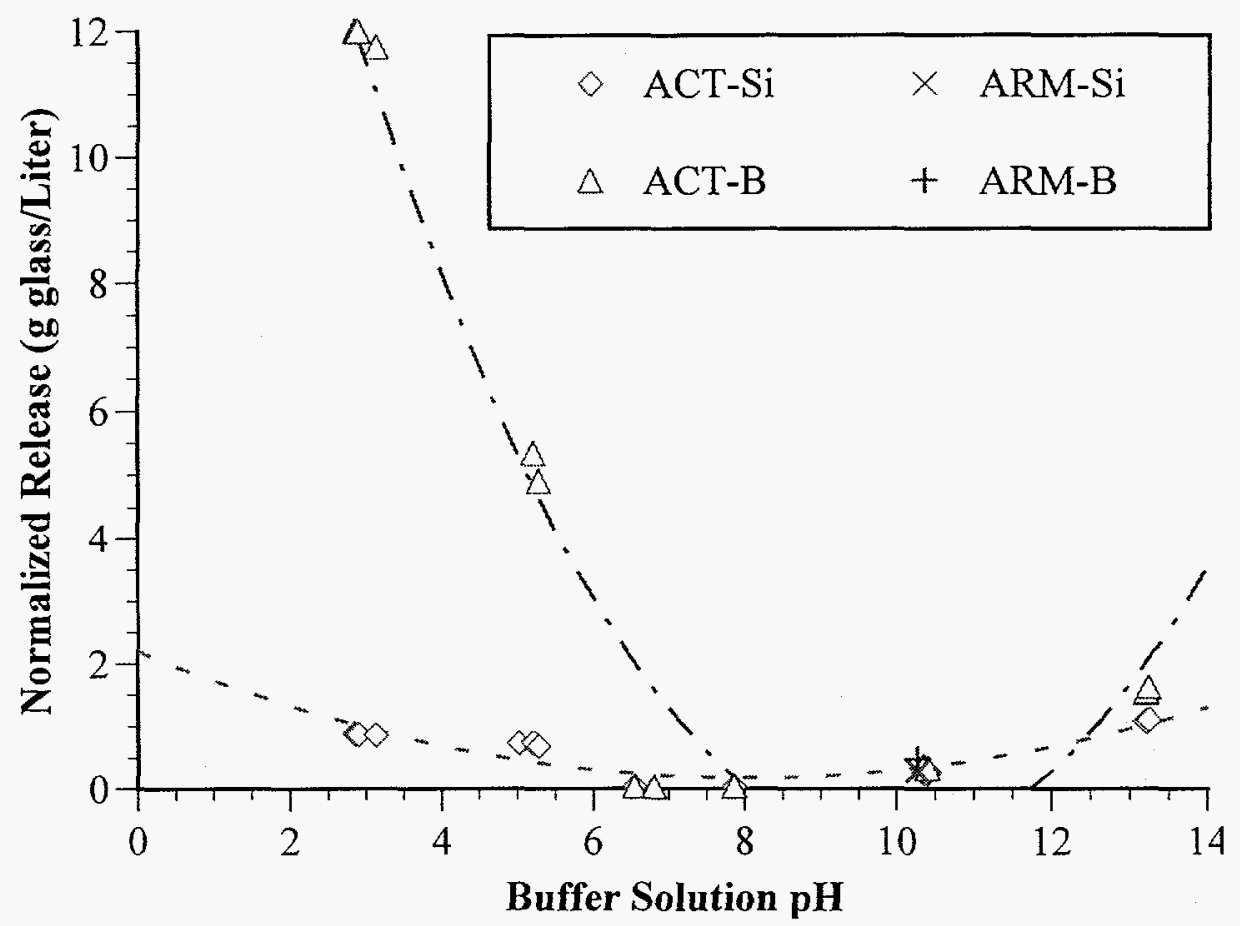

Figure 2. Am/Cm Target (ACT) silica and boron normalized elemental releases for different $\mathrm{pH}$ buffered solutions. 


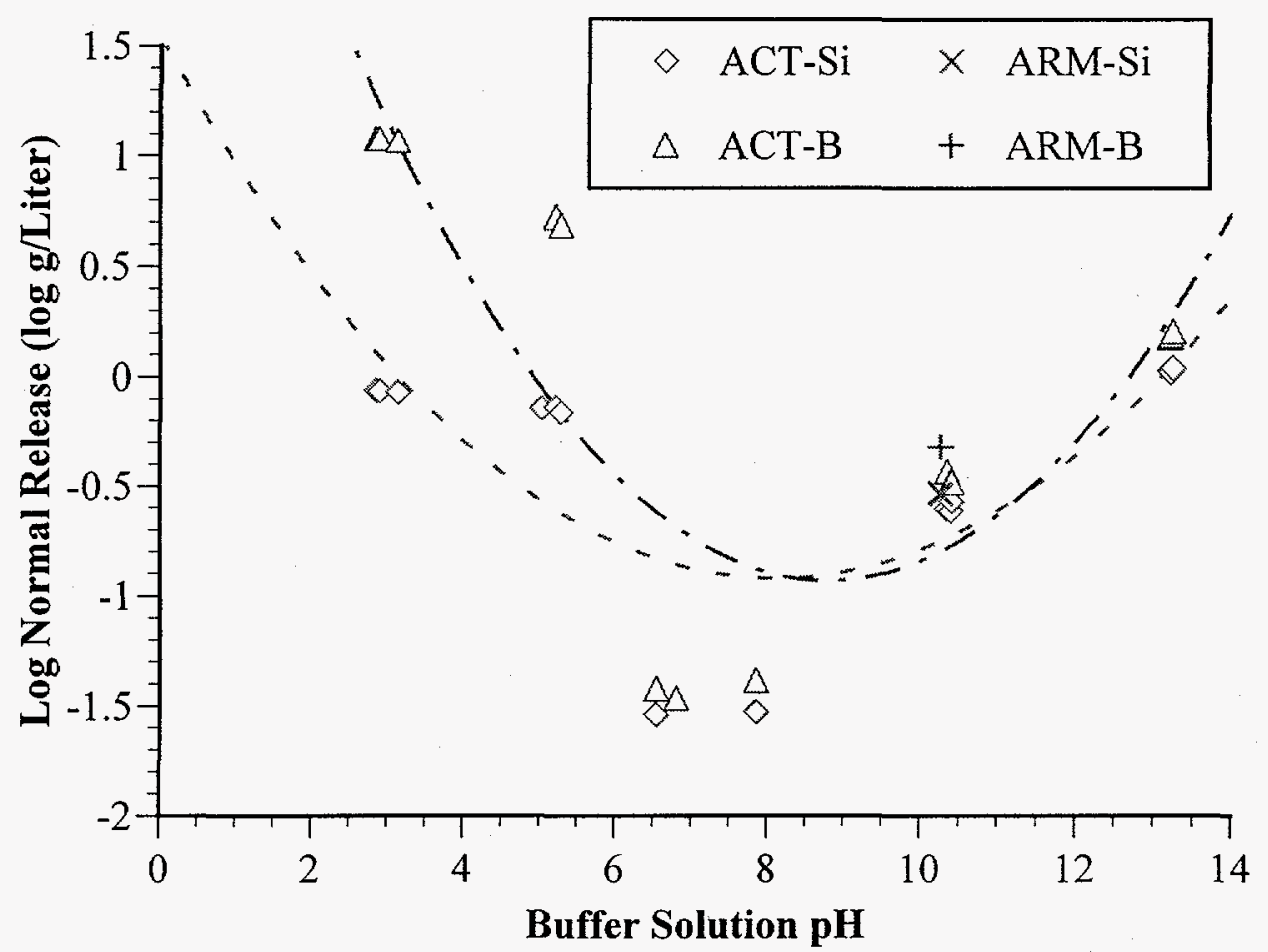

Figure 3. Am/Cm Target (ACT) silica and boron log normal elemental releases for different $\mathrm{pH}$ buffered solutions.

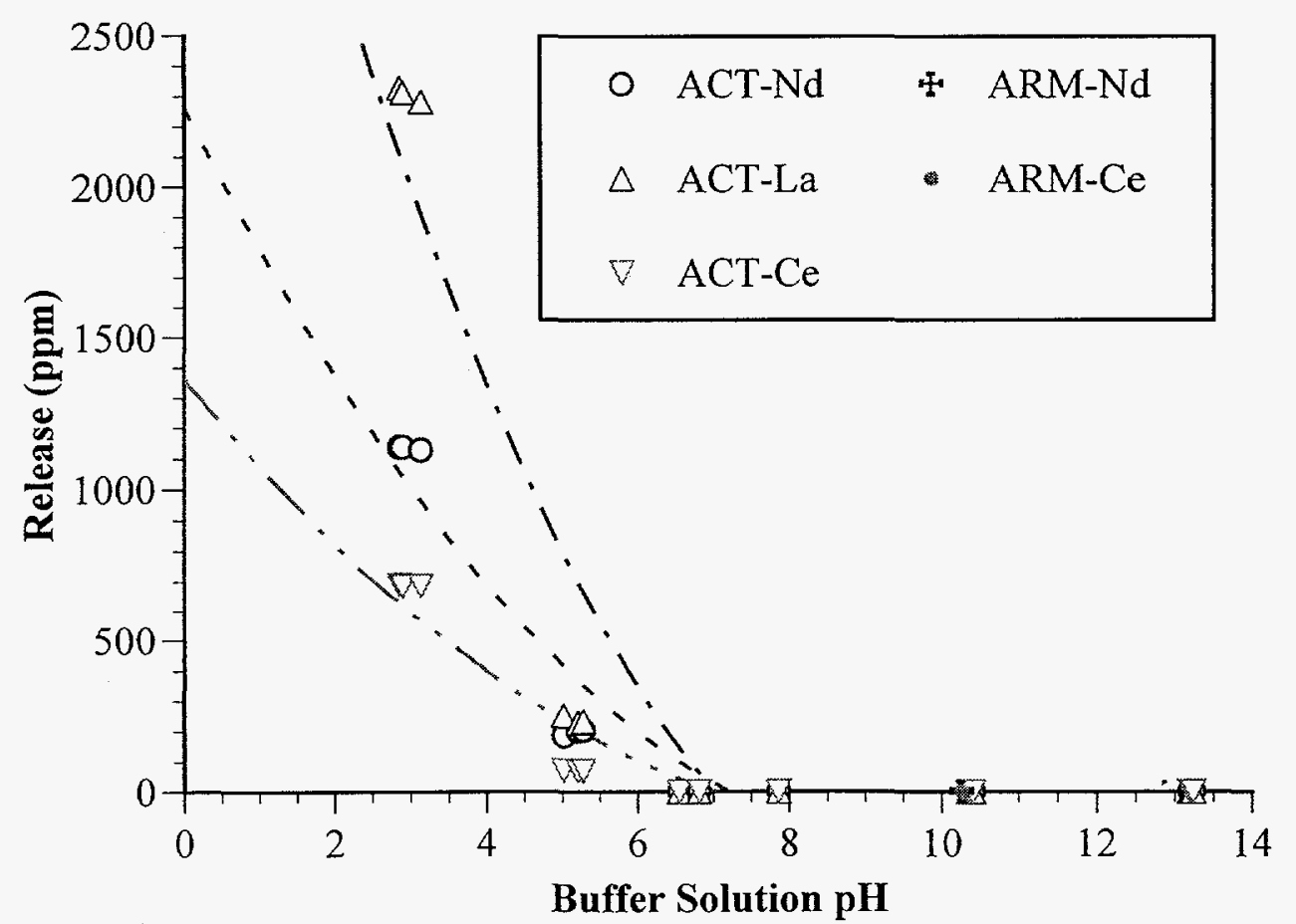

Figure 4. Am/ $\mathrm{Cm}$ Target (ACT) actinide surrogate leachate concentrations for different $\mathrm{pH}$ buffered solutions. 


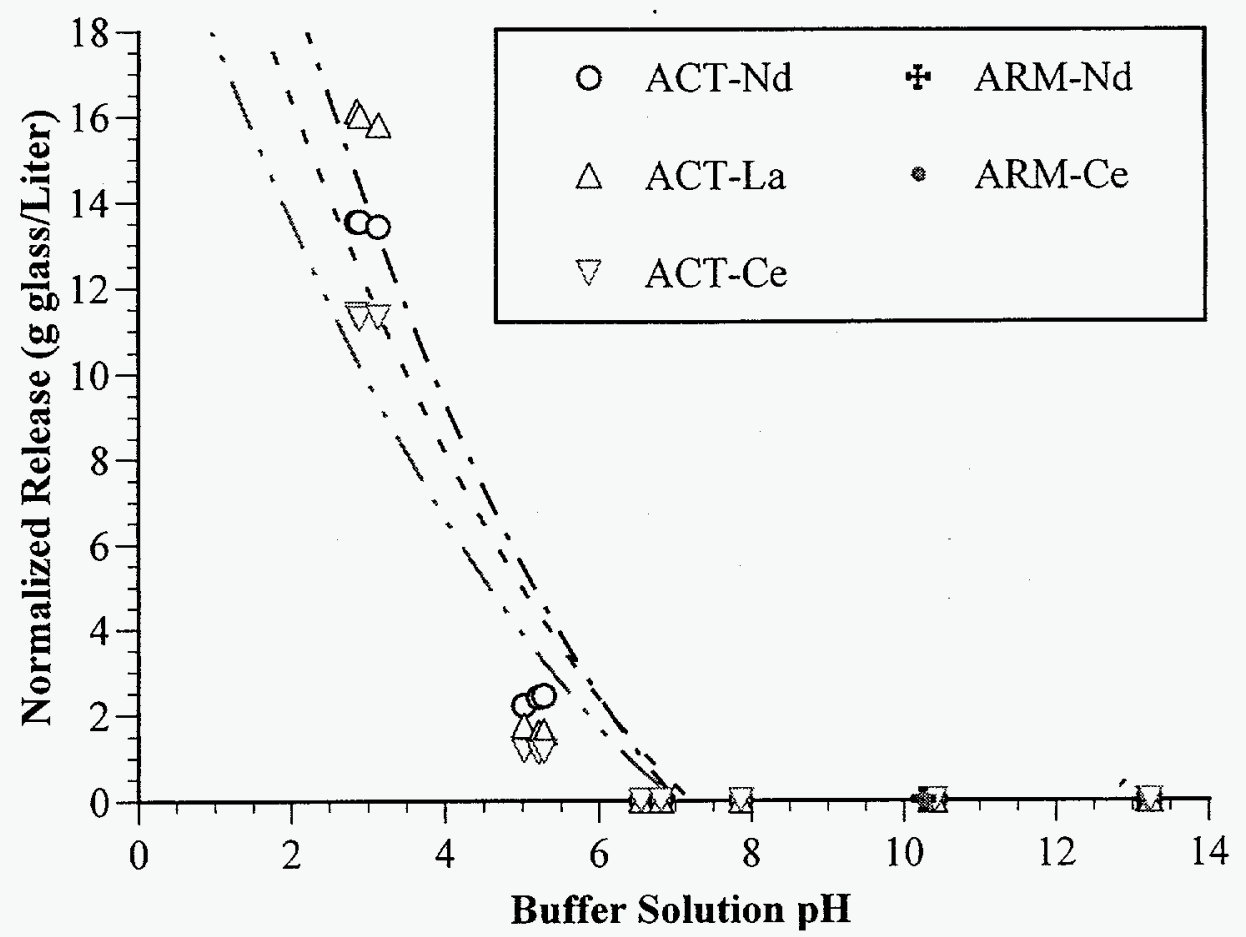

Figure 5. Am/Cm Target (ACT) actinide surrogate normalized elemental releases for different $\mathrm{pH}$ buffered solutions.

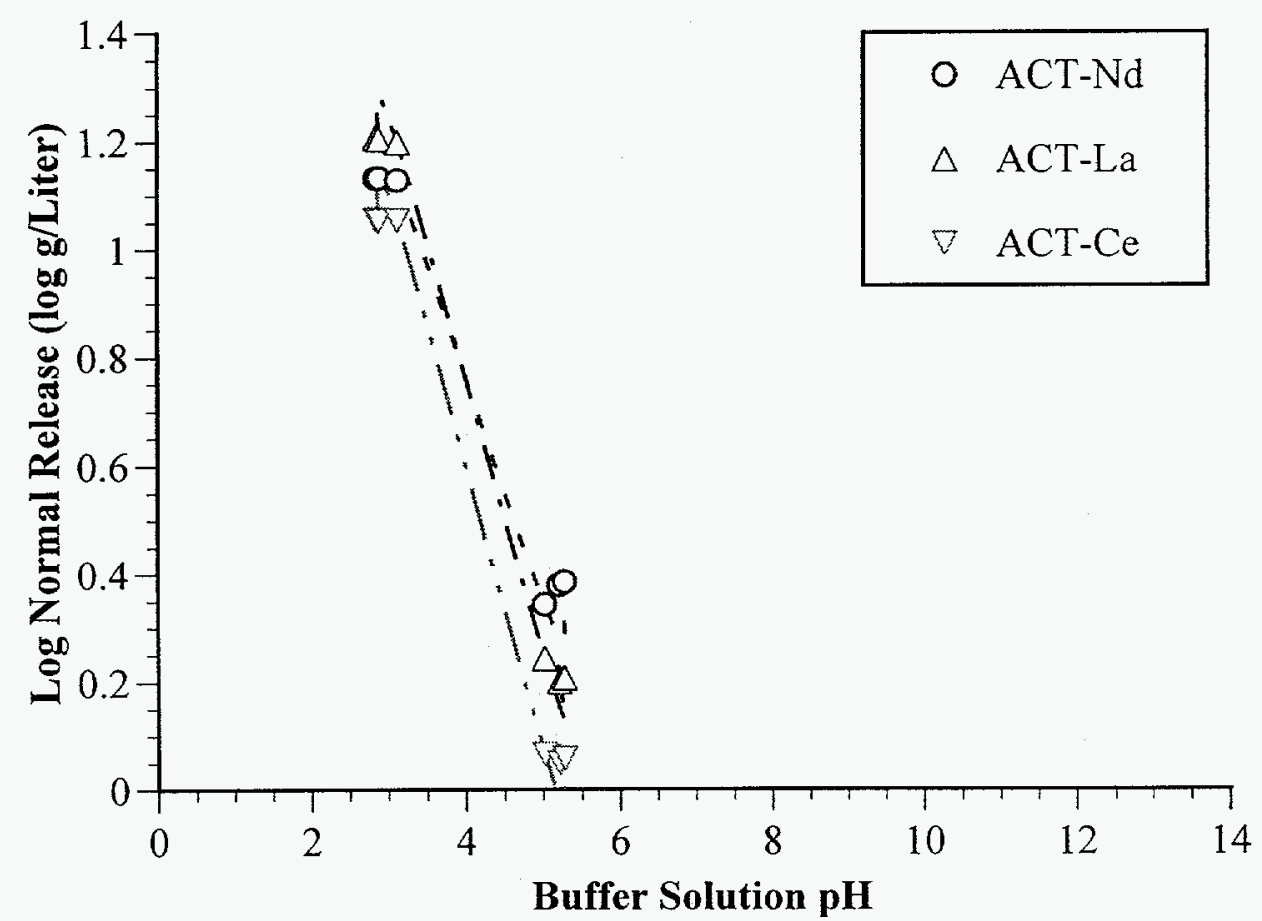

Figure 6. Am/Cm Target (ACT) actinide surrogate log-n ormal elemental $\mathrm{r}$ eleases for different $\mathrm{pH}$ buffered solutions. 


\section{Conclusions}

These experimental studies on $\mathrm{Am} / \mathrm{Cm}$ Target glass have shown that its durability is dependent on $\mathrm{pH}$. As the $\mathrm{pH}$ of the solution decreases away from a neutral $\mathrm{pH}$, the elemental releases increase orders of magnitude. Looking at the boron releases, the dissolution is around zero at a neutral $\mathrm{pH}$ and rapidly rises to approximately 12 grams of glass dissolved per liter of solution at a $\mathrm{pH}$ of 3. The releases of the actinide surrogates ( $\mathrm{Nd}, \mathrm{La}, \mathrm{Ce}$ ) exhibit the same type of behavior, where the normalized release is about zero around a neutral $\mathrm{pH}$ and is around 14 grams of glass dissolved per liter of solution around a pH of 3 . These findings support using the $\mathrm{Am} / \mathrm{Cm}$ Target glass for storage of the actinides due to its high durability in aqueous or semi-neutral environments. These results also support the idea of using nitric acid to selectively extract the valuable isotopes from the $\mathrm{Am} / \mathrm{Cm}$ Target glass. Studies on nitric acid extraction of the real isotopes from the $\mathrm{Am} / \mathrm{Cm}$ Target glass have just been completed. Once that data becomes available, this report will be revised to include the new information. 